\title{
Ecophysiology of overwintering in the copepod Neocalanus plumchrus: changes in lipid and protein contents over a seasonal cycle
}

\author{
Robert W. Campbell ${ }^{1,3, *}$, Palmira Boutillier ${ }^{2}$, John F. Dower ${ }^{1,2}$ \\ ${ }^{1}$ School of Earth and Ocean Sciences, University of Victoria, PO Box 3055 Stn CSC, Victoria, British Columbia V8W 3P6, Canada \\ ${ }^{2}$ Department of Biology, University of Victoria, PO Box 3020 Station CSC, Victoria, British Columbia V8W 3N5, Canada \\ ${ }^{3}$ Present address: Institute for Hydrobiology and Fisheries Science, University of Hamburg, Olbersweg 24, 22767 Hamburg, Germany
}

\begin{abstract}
Changes in lipid and protein content, and the activity of the enzyme glutamate dehydrogenase $(\mathrm{GDH})$ were measured in a relatively isolated population of Neocalanus plumchrus in the Strait of Georgia between December 2001 and March 2003. Lipid contents (primarily wax esters, WE) were highest in overwintering Stage 5 copepodids, and consumption of wax ester stores began approximately 2 mo prior to moulting in situ. The rate of WE use in the in situ population, estimated from changes in WE over time, was $1.5 \mu \mathrm{g}$ individual ${ }^{-1} \mathrm{~d}^{-1}$, with approximately $28 \%$ of total wax ester reserves used prior to moulting. Loss rates in laboratory incubations ranged from 2.7 to $7.8 \mu \mathrm{g}$ individual $^{-1} \mathrm{~d}^{-1}$, with 36 to $65 \%$ of total wax ester reserves being used prior to moulting. Protein declined following the moult to adulthood, and was variable in active, surface-dwelling CV copepodids. Measurements of GDH activity were consistent with protein catabolism for actively growing CV copepodids and adults, but not overwintering individuals, which suggests that protein is not an important metabolic substrate during overwintering. Individuals kept in the laboratory moulted in advance of the in situ moulting period, after a 1 to 2 mo post-capture lag. Individuals collected early in the overwintering period postponed moulting relative to individuals collected closer to the time of the in situ moulting period. This suggests that the timing of moulting in $N$. plumchrus involves an interaction between an endogenous clock and an unknown cue that stimulates the termination of dormancy and the onset of reproductive development and maturation.
\end{abstract}

KEY WORDS: Copepod overwintering $\cdot$ Lipid physiology $\cdot$ Protein $\cdot$ Dormancy $\cdot$ Diapause

Resale or republication not permitted without written consent of the publisher

\section{INTRODUCTION}

Mid- to high-latitude pelagic ecosystems typically display strong seasonality in primary production, and the large calanoid copepods that dominate the mesozooplankton in those ecosystems have a similarly seasonal life history (e.g. Conover 1988). Growth of these copepods is generally confined to the fairly narrow period when primary production (and biomass) is high, with the remainder of the year spent in a dormant overwintering state, usually at considerable depth (Hirche 1996).

Dormancy can be defined as a 'state of suppressed development' and may be the result of quiescence or true diapause (Dahms 1995). Strictly speaking, diapause is a reduction in development triggered by environmental stimuli, and is ultimately under physiological (i.e. endocrine) control, while quiescence is an ad hoc reaction to a local environmental requirement (e.g. food, temperature; Danks 1987). Diapause is therefore obligatory, while quiescence is facultative. In insects, diapause is also persistent: diapause is not terminated until the proper token stimuli are received and the required physiological processes have occurred. In other words, true diapause is not terminated spontaneously, even if conditions become favourable (Tauber et al. 1986). However, all activity need not necessarily be curtailed during true diapause. Growth, mobility and feeding 
have all been observed in certain diapausing insects (Hodek 2002). The neurosecretions observed by Carlisle \& Pitman (1961) in Calanus finmarchicus, and the low levels of ecdysteroids in C. pacificus observed by Johnson (2003), are consistent with an endocrinemediated diapause stage in calanoid copepods.

The nature of dormancy in calanoid copepods is poorly described. The proximate cues to initiate dormancy are not known (Miller et al. 1991, Hirche 1996), but following the insect literature (e.g. Tauber et al. 1986), temperature, food availability and photoperiod are usually invoked. Similarly, the cues triggering the termination of dormancy have yet to be identified. Because water temperature does not vary much at the depths where most calanoids overwinter (usually hundreds of metres), it has been suggested that changes in photoperiod may be used as a cue to prompt termination (Miller et al. 1991). However, the photoperiod signal at depths $>500 \mathrm{~m}$ is very small. In addition, a modelling study by Hind et al. (2000) suggests that changes in photoperiod cannot explain the timing of emergence observed in geographically separated populations of Calanus finmarchicus. Instead, they found that normal development processes, operating at reduced (but temperature-controlled) rates, best explained observed patterns in timing.

Prior work with Calanus finmarchicus has suggested that overwintering dormancy is a quite fragile state (Grigg \& Bardwell 1982, Hirche 1983, 1989, Miller \& Grigg 1991). Grigg \& Bardwell (1982) incubated individuals in low, diffuse light and found that moulting occurred very quickly post-capture. Moulting occurred after a lag of 7 to $10 \mathrm{~d}$ early on in the overwintering period (August to November), and occurred immediately after capture later on in the season (January onwards). Miller \& Grigg (1991) similarly incubated groups of C. finmarchicus from the Gulf of Maine, but in various light regimes. Moulting was observed after a $\sim 1$ mo lag in individuals kept in constant illumination, and moulting was less consistent in treatments with different photoperiods (no evidence for a photoperiodic cue to terminate dormancy was found). Moulting was much more infrequent in dark treatments and with different photoperiods, usually with very little moulting occurring by the end of the experiments (which were terminated after $\sim 1.5$ mo). Hirche $(1983,1989)$ kept individual $C$. finmarchicus in the dark, and observed that moulting also occurred after about 1 mo. There is some question as to whether the animals used by Hirche (1983) were indeed dormant, because (1) they were collected from the near surface $(>100 \mathrm{~m})$, and (2) they had higher digestive enzyme activity than those from greater depths.

Overwintering calanoid copepods generally exhibit low metabolic rates, presumably as a strategy to con- serve metabolic and structural reserves to hedge against highly seasonal primary production (e.g. Hirche 1996). Respiration rates observed in overwintering copepods are usually quite low, presumably due to a reduction in lipid metabolism in order to preserve lipid reserves for use in gonadogenesis and reproduction (Conover 1988, Hirche 1996). Often, seasonal studies of lipid contents (or proxies for lipid content, e.g. C:N) have not observed significant use of lipids during overwintering (e.g. Ohman et al. 1989, Jónasdóttir 1999, Evanson et al. 2000). However, in studies with frequent sampling (monthly or less), dry weight and organic matter of Calanus finmarchicus has been observed to decline well in advance of spawning, and is assumed to have been caused by a reduction in lipid contents (Marshall \& Orr 1958, Comita et al. 1966, Tande 1982, Hopkins et al. 1984). Studies on the energetic costs of gonad development and moulting have shown that considerable amounts of lipids are required for the development from the CV to adult stage, between 36 and $60 \%$ for C. finmarchicus (Rey-Rassat et al. 2002), and between 40 and $80 \%$ for C. helgolandicus (Gatten et al. 1980, Rey-Rassat et al. 2002).

It has also been suggested that overwintering copepods may use protein as an energy source (Hirche 1996, Evanson et al. 2000). Evidence for protein use during overwintering includes observed declines in total protein content (Kirkesæerer 1977); declines in nitrogen content (Tande 1982, Ohman et al. 1989); low but measurable rates of ammonium excretion (Conover \& Corner 1968, Cowen 1982); and low O:N ratios (Conover \& Corner 1968, Kosobokova 1990, Schnack-Schiel 2001). Calanoid copepods are primarily ammonotelic, whereby the catabolism of proteins and nucleic acids produces ammonium (Corner \& Cowey 1968). In order to be catabolised, protein is broken down into amino acids by various proteases, then transaminated with $\alpha$-ketoglutarate to produce $\alpha$-keto acids and glutamate. Glutamate is then oxidised by glutamate dehydrogenase (GDH) into ammonium, $\mathrm{NADH}$, and a proton (Bidigare \& King 1981). GDH activity may therefore be assayed by observing changes in the production of NADH in cell-free homogenates. Comparison of GDH activity with ammonium production have shown good correlations in some studies (Bidigare \& King 1981, Ikeda et al. 2000, and references therein). However, Berges et al. (1993) found that GDH activity was related to body size but not to growth or feeding condition in Artemia salina, and Hernández-León \& Torres (1997) found considerable variability in GDH:ammonium production ratios in mixed zooplankton.

In the subarctic Pacific, mesozooplankton biomass is dominated by 3 species of the genus Neocalanus (e.g. Miller et al. 1984). N. plumchrus, N. flemingeri and $N$. 
cristatus spend most of the year at depth in a dormant state. Arousal, moulting, and spawning all occur at depth as well. Naupliar and copepodid stages migrate to the surface, where growth and development occurs, followed by a downward migration by late-stage copepodids (Stage 4 to adult, depending on species and locale: Mackas \& Tsuda 1999). Subarctic Pacific species of Neocalanus differ from other calanoid copepod genera in that adult mouthparts are non-functional, and all development and spawning is fuelled by endogenous lipid reserves (Fulton 1973, Miller et al. 1984). Neocalanus spp. thus represents an excellent model with which to study physiological changes during the termination of overwintering, because the potentially confounding factor of food requirements is absent.

The objectives of the present study were to quantify the changes in lipid and protein contents over the course of the life history of late-stage Neocalanus plumchrus. In order to accomplish this, we have used measurements from both an in situ population and from laboratory incubations. We chose the Strait of Georgia for our study site because it hosts a population of $N$. plumchrus that can be sampled with relative ease throughout the year and that exhibits a highly synchronised life history (Fulton 1973).

\section{MATERIALS AND METHODS}

Collection. Copepods were collected from a single site over the deepest part $(\sim 400 \mathrm{~m})$ of the Strait of Georgia $\left(49^{\circ} 15^{\prime} \mathrm{N}, 123^{\circ} 45^{\prime} \mathrm{W}\right)$ using a closing SCORtype net (57 $\mathrm{cm}$ mouth diameter, $236 \mu \mathrm{m}$ mesh) towed vertically at $\sim 0.5 \mathrm{~m} \mathrm{~s}^{-1}$. We sampled 4 strata (0 to 100 , 100 to 200,200 to 300 and 300 to $400 \mathrm{~m})$. Upon retrieval, the net was rinsed and the sample split with a Motoda splitter (Motoda 1959), and half the sample preserved in 3 to $4 \%$ formalin for subsequent enumeration. Only Stage CV and adult stages were enumerated. Samples for the analysis of lipid contents were removed from the second half, with approximately 5 lots of Neocalanus plumchrus (usually 4 individuals per lot) picked out under a stereomicroscope, placed into folded, precombusted $25 \mathrm{~mm}$ glass-fibre filters, and then frozen immediately in liquid nitrogen. Replicate samples were not collected between December 2001 and May 2002 (i.e. there was 1 lot of 4 individuals only). The time between collection and freezing was $<15$ min.

In 2002, only CV copepodids were collected for lipid analysis, while in 2003 adult males and females were also collected. Females were split into 3 groups: 'undeveloped' (gonad undeveloped, oviducts empty), 'gravid' (gonad developed, oocytes present in oviducts), and 'spent' (gonad and oviducts empty, or with $<6$ individual oocytes). The former 2 categories are analogous to Stage 1 and Stages 3 to 7 of Runge (1987) respectively. Individuals in intermediate stages of development (e.g. oocytes present in ovaries, but not fully developed) were encountered infrequently, and were included as 'gravid'.

Samples for the analysis of protein contents and GDH activity were also removed from the second half of each net sample. Initially, aliquots of approximately 20 individuals were removed and filtered onto a small square of Nitex mesh that was then folded, placed in a cryovial, and frozen in liquid nitrogen. Part-way through the study it was found that it was not possible to accurately stage adults upon thawing (such samples are therefore designated as 'mixed'). Thereafter, beginning in March 2002, lots with 10 to 20 individuals (usually 3 lots per depth) were sorted by stage and frozen separately on combusted glass-fibre filters. Hydrographic properties at the sampling site were measured with a SeaBird model 19-plus or Model 25 CTD.

Copepods to be used for incubations were collected using the same SCOR net, with a closed codend attached, towed vertically from 400 to $200 \mathrm{~m}$ at $\sim 0.25 \mathrm{~m} \mathrm{~s}^{-1}$. Upon retrieval, the codend was immediately emptied (without rinsing the net) into a cooler filled with $\sim 301$ of $300 \mathrm{~m}$ seawater. Groups of 25 to 30 individuals were removed from the cooler and transferred immediately into 21 glass jars filled with water from $300 \mathrm{~m}$ depth that had previously been filtered through a G/F75 filter (AMD Manufacturing; $0.7 \mu \mathrm{m}$ nominal pore size). Jars were filled to the brim and sealed without any air bubbles, and transported back to the laboratory in the dark in seawater-filled coolers with ice packs.

Incubations. Upon arrival in the laboratory, jars were placed in a dark, $9^{\circ} \mathrm{C}$ cold room. Preliminary attempts with incubations had resulted in mass mortality, presumably from oxygen depletion by bacterial respiration following moulting by the copepods. It was preferable not to disturb the copepods during incubation by changing the water, so each jar was initially spiked with $1 \mathrm{ml}$ of broad spectrum antibiotic (Invitrogen PSN antibiotic mixture, Cat. No. 15640055). The concentrations of antibiotics used were very low (penicillin and streptomycin: $2.5 \mu \mathrm{g} \mathrm{ml}{ }^{-1}$, neomycin: $5 \mu \mathrm{g} \mathrm{ml}^{-1}$ ), but sufficient to prevent oxygen depletion during the course of the incubations.

At each time point of an incubation, 1 jar was sacrificed for lipid analysis and 1 for determination of protein and GDH activity. Individuals were removed from each jar, the stage of each was noted, and they were then frozen in liquid nitrogen. Samples for analysis of lipids were sorted by stage (1 to 4 individuals, depending on the availability of each stage) and frozen on a 
precombusted glass-fibre filter, while samples for the analysis of protein content/GDH activity were not sorted by stage, and were frozen in Nitex squares (in the same manner as the in situ samples). Time points were spaced close together at the beginning of the incubations ( 1 to $3 \mathrm{~d}$ ), and more widely ( 2 to $4 \mathrm{wk}$ ) as the incubations progressed. The number of jars per incubation (usually 18 to 24, but as few as 10 in January 2003) depended on the number of copepods collected and time constraints at sea, so time points were not the same for all incubations. Instead, they were spaced out to cover the individual incubation times as satisfactorily as possible. Mortality during the incubations was quite low initially $(<8 \%)$, and generally occurred after moulting to adulthood had begun ( $\sim 4$ to $6 \mathrm{wk}$ ). At later time points (post-spawning) mortality was quite high, around $80 \%$, involving large numbers of spent adults (i.e. with no visible lipid stores or musculature). Only live individuals were retained for lipid analysis. Moulting failure was uncommon; out of all the incubations, only 3 individuals were found entangled in their exuvium.

Lipids. Each filter (with its lot of frozen copepods) was placed in an extraction medium of 2:1 (v/v) chloroform:methanol, to which a known concentration of 3-hexadecanone had been added as an internal standard. The extraction medium and sample was homogenised with a Branson Model 250 ultrasonic homogeniser (2 min duration, $75 \%$ duty cycle, power level $40 \mathrm{~W})$. The filter was removed prior to homogenisation, and temperature increases were reduced by suspending the sample in a dry ice-ethanol bath. The homogenate and filter were stored at $-15^{\circ} \mathrm{C}$ for $24 \mathrm{~h}$ after homogenisation to complete the extraction. Following the extraction period, deionised distilled water (with $0.9 \% \mathrm{NaCl}$ added) was added to bring the extraction medium to 8:4:3 chloroform:methanol:water (v/v/v; Folch et al. 1957) and the sample was centrifuged for $5 \mathrm{~min}$ at $1500 \times g$ in a swinging basket-centrifuge to allow phases to form. The filter was then moved into the upper phase for 5 min to allow any chloroform to sink out. The sample was then recentrifuged for $5 \mathrm{~min}$ and the lower phase was pipetted out, dried under argon gas, and resuspended in hexane. The amount of hexane used was adjusted depending on the number of individuals in the lot, and varied between $75 \mu \mathrm{l}$ (1 individual) and $300 \mu \mathrm{l}$ (4 individuals).

Analysis of lipid classes was performed using an Iatroscan MK-5 TLC/FID analyser. A $1 \mu$ laliquot of the concentrated lipids in hexane was spotted onto an S-III chromarod, with a custom spotter (similar to that of the MkII spotter of Read 1985) and a $2 \mu$ l Hamilton syringe. Sample application by the syringe was controlled with a microprocessor-controlled electronic linear actuator and the chromarod was rotated at $\sim 20 \mathrm{rpm}$ by a second small motor during application. Separation of lipid classes was done with a modification of the doubledevelopment techniques of Ohman (1988) and Miller et al. (1998). The chromarods were developed twice in 95:5 (v/v) hexane:diethyl ether for $30 \mathrm{~min}$ and once in 66:14:0.1 (v/v) hexane:diethyl ether:formic acid for $19 \mathrm{~min}$. The chromarods were humidified over saturated $\mathrm{CaCl}_{2}$ for 5 min before each development, and dried at $60^{\circ} \mathrm{C}$ for $5 \mathrm{~min}$ after each development.

Recording of the chromatograms during FID (flame ionisation detector) scans and calculation of peak areas was done with a PeakSimple ${ }^{\circledR}$ chromatography data system (SRI Instruments). Analytical standards were tripalmitin (triacylglycerols: TAG), palmitic acid (free fatty acids: FFA), cholesterol (sterols: ST) and DL- $\alpha-$ phosphatidylcholine, dipalmitoyl (polar lipids: PL). Recovery of phospholipids (which may not dissolve entirely in hexane: Ackman et al. 1990) was not tested. Wax ester/steryl ester standards were purified from various lots of field-collected individuals ( 300) using the method of Ohman (1997). Marine wax esters (WE) as separated by TLC have been observed to contain small amounts of steryl esters ( $\mathrm{SE}_{;} \sim 8 \%$ in sediment trap samples: Hudson et al. 2001). The SE content of marine copepods is not well described, but they have not been observed in large calanoid copepods (Neocalanus tonsus: Ohman et al. 1989; Calanus hyperboreus: Kehoe 2003), and we will refer to SE and WE collectively as simply WE. Calibration curves were made with 6 levels, and were fit to power functions for all classes but PL, for which a linear fit was used; $r^{2}$ values were $>0.96$, and usually 0.98 to 0.99 .

Protein content and GDH activity. To determine protein content and enzyme activity, we modified the methods of Bidigare \& King (1981) and Smith et al. (1985) in order to make multiple measurements from the same homogenate. For each sample, the Nitex square or filter was thawed, and $\leq 20$ individuals were placed in $1 \mathrm{ml}$ of homogenisation medium (0.1 M Tris buffer with $2 \mathrm{ml} \mathrm{l}^{-1}$ Triton $\mathrm{X}-100$ made up to $\mathrm{pH} 8.5$ with $\mathrm{HCl}$ ). The copepods and homogenisation medium were then sonicated (1 min duration, $70 \%$ duty cycle, power level $40 \mathrm{~W}$ ). The sample was suspended in a dry ice-ethanol bath during homogenisation in order to reduce temperature increases. The homogenised samples were centrifuged for $5 \mathrm{~min}$ at $1500 \times g$ in a swinging basket-centrifuge prior to removing aliquots for the GDH assay and protein determination. Samples were kept on ice prior to all assays in order to reduce enzyme activity.

Protein content was determined by the Binchoninic acid assay of Smith et al. (1985). The method uses a single standard working reagent (SWR) that is 50 parts Reagent A (10 g l$~^{-1}$ bicinchoninic acid, $20 \mathrm{~g} \mathrm{l}^{-1} \mathrm{Na}_{2} \mathrm{CO}_{3}$, $1.6 \mathrm{~g} \mathrm{l}^{-1}$ sodium tartrate, $4 \mathrm{~g} \mathrm{l}^{-1} \mathrm{NaOH}$ and $9.5 \mathrm{~g} \mathrm{l}^{-1}$ 
$\mathrm{NaHCO}_{3}$, adjusted to $\mathrm{pH} 11.25$ with $10 \mathrm{M} \mathrm{NaOH}$ ) to 1 part Reagent B (40 g l$^{-1}$ copper [II] sulphate pentahydrate). SWR is stable for at least $1 \mathrm{wk}$, but a fresh batch of SWR was made up for each homogenisation. Protein content was measured by mixing the homogenate with SWR 1:20 (v/v), incubating for $30 \mathrm{~min}$ at $40^{\circ} \mathrm{C}$, and measuring absorbance against a homogenisation buffer blank at $562 \mathrm{~nm}$. Typically, $100 \mu$ l aliquots of homogenate were mixed with $2 \mathrm{ml}$ of SWR, although in samples with a large number of individuals (which saturated the absorbance), smaller aliquots were removed and topped up to $100 \mu$ with homogenisation buffer. Standards for calibration curves were made up with bovine serum albumin, and absorbance was read on an LKB Ultrospec II spectrophotometer.

GDH activity was assayed using modifications of the techniques of Bidigare \& King (1981) and Bidigare et al. (1982). Since our homogenates contained a smaller amount of material, we improved the response by using a larger volume of homogenate $(350 \mu \mathrm{l})$, and adjusting the amount and concentration of reagents accordingly, in order to achieve the same final concentrations as Bidigare et al. (1982). The reaction mixture had a volume of $1.1 \mathrm{ml}$, and contained $2 \mathrm{mM} \mathrm{ADP}$, $1.2 \mathrm{mM} \mathrm{NAD}^{+}$, and $40 \mathrm{mM}$ glutamate. All reagents were added separately $(125,125$ and $500 \mu$ respectively), and glutamate was always added last. Prior to running the assay, samples were centrifuged at $10000 \times g$ for $10 \mathrm{~min}$ in a fixed-angle rotor in a refrigerated centrifuge at $2^{\circ} \mathrm{C}$ in order to remove any suspended matter. GDH activity was estimated by measuring the increase in absorbance at $340 \mathrm{~nm}$ following the addition of glutamate, using a CARY 5 spectrophotometer fitted with a temperature-controlled block operating at $9^{\circ} \mathrm{C}$. All reagents were stored in unused cells of the block prior to the assay, to allow them to cool to $9^{\circ} \mathrm{C}$ as well. Absorbance was measured at $1 \mathrm{~s}$ intervals, and the difference in absorbance in the linear region of the curve (between 20 and $70 \mathrm{~s}$ ) was used to calculate the rate of change of absorbance. Occasionally, local minima were observed in the early part of the absorbance trace, and were attributed to resuspended particulates from the centrifuge tube wall that were aspirated while pipetting the homogenate. In those instances, a shorter time interval (but still ending at $70 \mathrm{~s}$ ) was used to avoid such minima.

Calibration of GDH activity. In order to relate the observed GDH activities to ammonium excretion rates, a number of calibration incubations were carried out using individuals collected from the study station in April 2003. A total of 4 incubations were set up in $300 \mathrm{ml}$ stoppered BOD bottles containing between 22 and 51 individuals in $0.7 \mu \mathrm{m}$-filtered seawater, as well as initial $\left(t_{0}\right)$ controls and filtered seawater-only controls; $t_{0}$ controls were measured upon return to the laboratory (approximately $3 \mathrm{~h}$ after the incubations were set up). Incubations and copepod-free controls were measured following a $24 \mathrm{~h}$ incubation period. Ammonium concentrations were measured after Koroleff (1983). Following the removal of water for ammonium determinations, all individuals were removed from the bottles, frozen in liquid nitrogen, and GDH activities determined as described above. GDH activity:ammonium excretion in the incubations was $15.3 \pm$ $4.3($ mean $\pm \mathrm{SD})$.

In order to include the effect of temperature on metabolic rate, enzyme activities that are not measured at in situ temperatures are often corrected with the Arrhenious equation (Owens \& King 1975). For the purposes of this study, we did not correct measured enzyme activities, and will confine our discussion to changes in physiology, not excretory products. The GDH assay was done at $9^{\circ} \mathrm{C}$, and the temperatures experienced by Neocalanus plumchrus during overwintering at depth (200 to $400 \mathrm{~m})$ in the Strait of Georgia do not vary greatly $\left(\sim 9\right.$ to $\left.9.5^{\circ} \mathrm{C}\right)$; the incubations were also held at a constant $9^{\circ} \mathrm{C}$. We have used the measured GDH: $\mathrm{NH}_{4}{ }^{+}$excretion ratio to convert our measurements of activity to excretion rates (the currency used by other workers), but we note that our calculated rates for individuals at the surface (where temperatures were higher) are likely to be underestimates of actual in situ excretion rates. Furthermore, GDH 'activity' is simply a measurement of the amount of $\mathrm{NAD}^{+}$that is reduced to $\mathrm{NADH}$ by $\mathrm{GDH}$ in the presence of unlimited substrates (glutamate and ADP). Therefore, any GDH that is present will be operating at maximum rate, $V_{\max }$ and the amount of NADH produced over a small time period will simply be a function of the amount of enzyme present. Thus, because we did not directly measure the amount of enzyme present, we will use the term $\mathrm{GDH}$ 'activity', but note that what was actually measured is a proxy for the amount of enzyme present in the homogenate.

\section{RESULTS}

\section{Strait of Georgia population}

Temperature and salinity at depth changed only slightly during the overwintering period (Fig. 1). Relative to the time that the copepods descended to depth (April to May), temperature and salinity increased by approximately $0.5^{\circ} \mathrm{C}$ and $0.5 \mathrm{psu}$ beginning in September 2003, as a consequence of deep-water renewal processes that usually occur in late summer (LeBlond et al. 1991). 


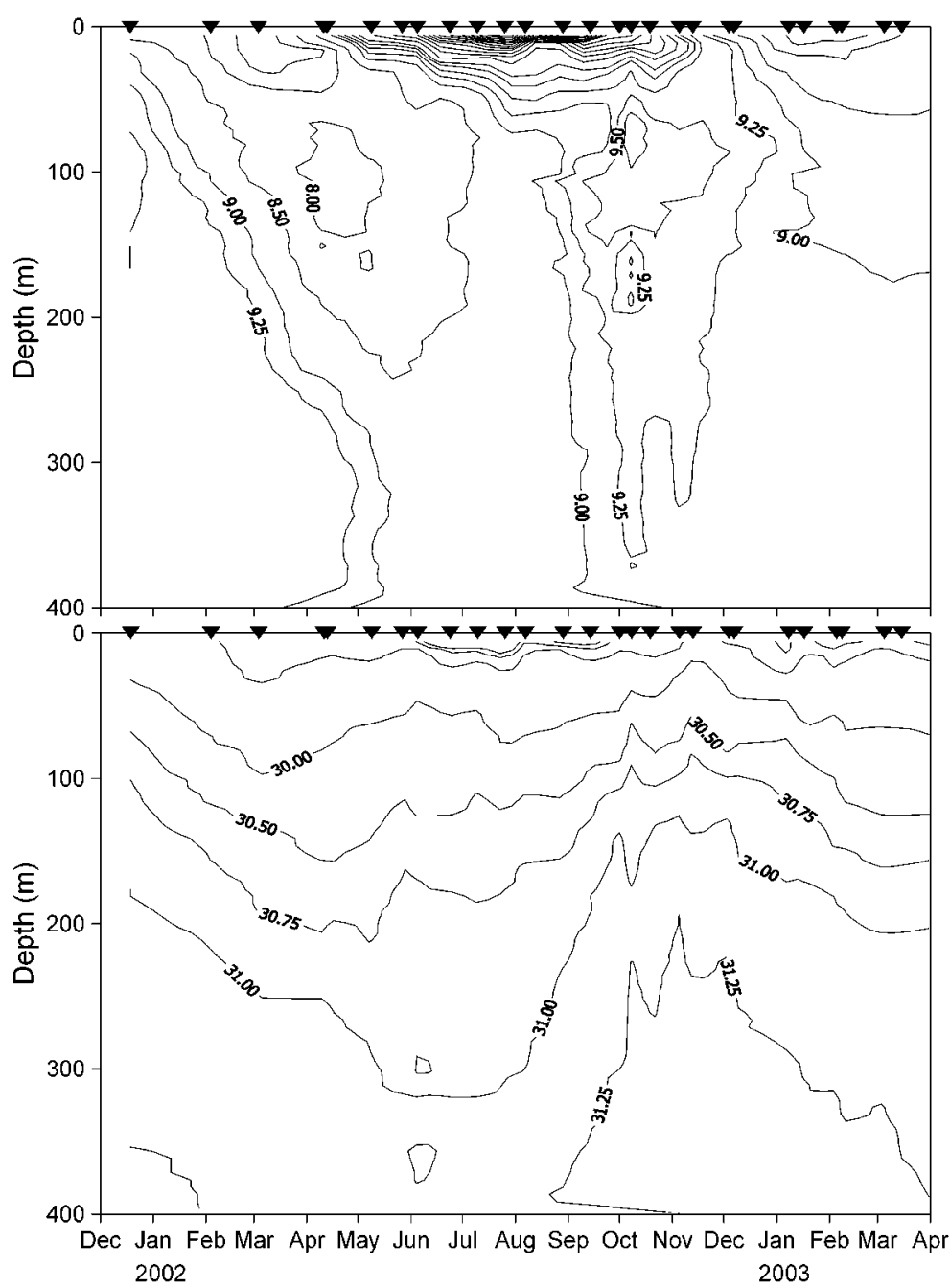

Fig. 1. Seasonal variation in temperature $\left({ }^{\circ} \mathrm{C}\right.$ : top graph) and salinity (psu: bottom graph) in the Strait of Georgia $\left(49^{\circ} 15^{\prime} \mathrm{N}\right.$, $123^{\circ} 45^{\prime} \mathrm{W}$ ) from Jan 2002 to May 2003. Isotherms and isohalines were fit by linear interpolation ( $5 \mathrm{~m}$ vertical spacing, $14 \mathrm{~d}$ temporal spacing) of $1 \mathrm{~m}$ binned CTD data. ( $\boldsymbol{\nabla})$ denote sampling dates. Data from the STRATOGEM project (www.stratogem.ubc.ca) were incorporated, along with CTD casts done during net sampling instances, to improve temporal resolution

The overwintering stock of Neocalanus plumchrus was composed primarily of CV copepodids (1 precocious male was captured in late June of 2002; Fig. 2A), and were always confined to depths below $200 \mathrm{~m}$. Adults appeared in late December or early January. In 2001, only adult males were captured in December, while adult males and immature females were observed coincidently in January of 2003. Adults were distributed slightly shallower in the water column than were CVs, and were captured in the 3 strata between $100 \mathrm{~m}$ and the bottom. CV copepodids were only observed shallower than $200 \mathrm{~m}$ in March and April 2003, and presumably represented the 2003 generation.

\section{Lipids}

No consistent differences were observed among individuals in different depth ranges, and samples are therefore not distinguished by depth. Lipid contents (for all classes of lipids measured) were generally highest in overwintering individuals, and declined progressively towards the end of the overwintering period (Fig. 2). WE content of $\mathrm{CV}$ copepodids declined from an average of $627 \pm 168 \mu \mathrm{g}( \pm \mathrm{SD})$ in October 2002 to $461 \pm 73 \mu \mathrm{g}$ in January 2003, an average decline of $26 \%$. The rate of lipid utilisation may also be inferred by regression of WE content through time. A linear model (WE $=\alpha+\beta t$, where $t=$ time in days) gave a lipid utilisation rate $(\beta)$ of $-1.5 \mu \mathrm{g}$ individual $^{-1}$ $\mathrm{d}^{-1}$, for an overall decrease between October and January of $167 \mu \mathrm{g}$ ind. ${ }^{-1}$, or $28 \%\left(\alpha=597, \mathrm{r}^{2}=0.19\right.$, $\left.\mathrm{p}_{\text {ANOVA }}=0.006\right)$. Following moulting, adults rapidly used up most of their remaining wax ester contents over the next 1 to 2 mo. Males were only observed on 2 occasions (January and February 2002), and lipid contents declined from an average of 380 to $171 \mu \mathrm{g}$ ind..$^{-1}$, a loss rate of $9.95 \mu \mathrm{g}$ ind..$^{-1} \mathrm{~d}^{-1}$. Females (all gonad stages combined) lost WE contents at $7.09 \mu \mathrm{g}$ ind.$^{-1} \mathrm{~d}^{-1}(\alpha=478$, $\left.\mathrm{r}^{2}=0.62, \mathrm{p}<0.0001\right)$ between January and March 2003, although this rate is probably an underestimate since females may progress from 'gravid' to 'spent' at a greater rate than was measured with the temporal resolution of this study.

TAG concentrations were generally very low through most of the year and particularly low when adults were present. TAG concentrations were usually in the order of 1 to $2 \%$ of WE concentrations, and the small number of samples with higher TAG:WE (4 to $10 \%$ ) were composed of gravid and spent females (i.e. with very low WE). FFA concentrations also began to increase between November and December, with smaller amounts occurring in adults. A similar pattern was observed in ST concentrations (not shown). The apparent increase in ST was most probably caused by an increase in free alcohols, since ST and alcohols elute to approximately the same region of the chromarod (Parrish 1987), and free alcohols could be expected as by-products of wax ester hydrolysis (see 'Discussion'); a free alcohol standard was not included in this study. Concentrations of PL were variable, and were lowest in adults. PL concentrations began to decline at approximately the same time that WE began to decline and FFA began to increase. FID response at low concentrations is non-linear, and has a coefficient of variation of $\sim 10 \%$ (Parrish \& Ackman 1985, Parrish 1987). Measurements of TAG and FFA were very low 
(i.e. near the detection limit of the technique), and the measurements reported here should be regarded with caution.

\section{Protein}

Protein content was highest in overwintering individuals, and showed a progressive decline in adults in both mixed and stage-discrete samples. The lowest values were recorded in spent females (Fig. 3A). Surfacedwelling Stage 5 copepodites (CV) had relatively low protein content (mean \pm SD $84.6 \pm 23.6 \mu \mathrm{g}$ ) in April 2002, but a relatively high (175.6 \pm $2.6 \mu \mathrm{g})$ protein content in April 2003. As with lipids, there were no significant depth-based differences in protein or GDH activity and samples are not distinguished by depth. There was no significant decline in protein contents during the 2002 overwintering period, and the slope of a linear regression of protein content versus day for CVs (May 2002 to January 2003) was not significantly different from zero $\left(\mathrm{p}_{t \text {-test }}=0.79\right)$.

GDH activity did not change consistently over the annual cycle (Fig. 3B). High activity was observed in some adults, and surface-dwelling CVs in 2002 only. Approximately half of the CVs overwintering at depth had high GDH activity in May to July 2002. GDH activity was not correlated with protein content $\left(\mathrm{r}_{\text {Pearson }}=0.01, \mathrm{p}=0.91\right)$, and closer examination of GDH activity and protein content of overwintering CVs (i.e. between May 2003 and February 2003: Fig. 4) shows that individuals with less protein tended to have higher GDH activity, while most of the individuals collected later in the season tended to have lower GDH activity.

\section{Incubations}

Post-capture behaviour of overwintering Neocalanus plumchrus was
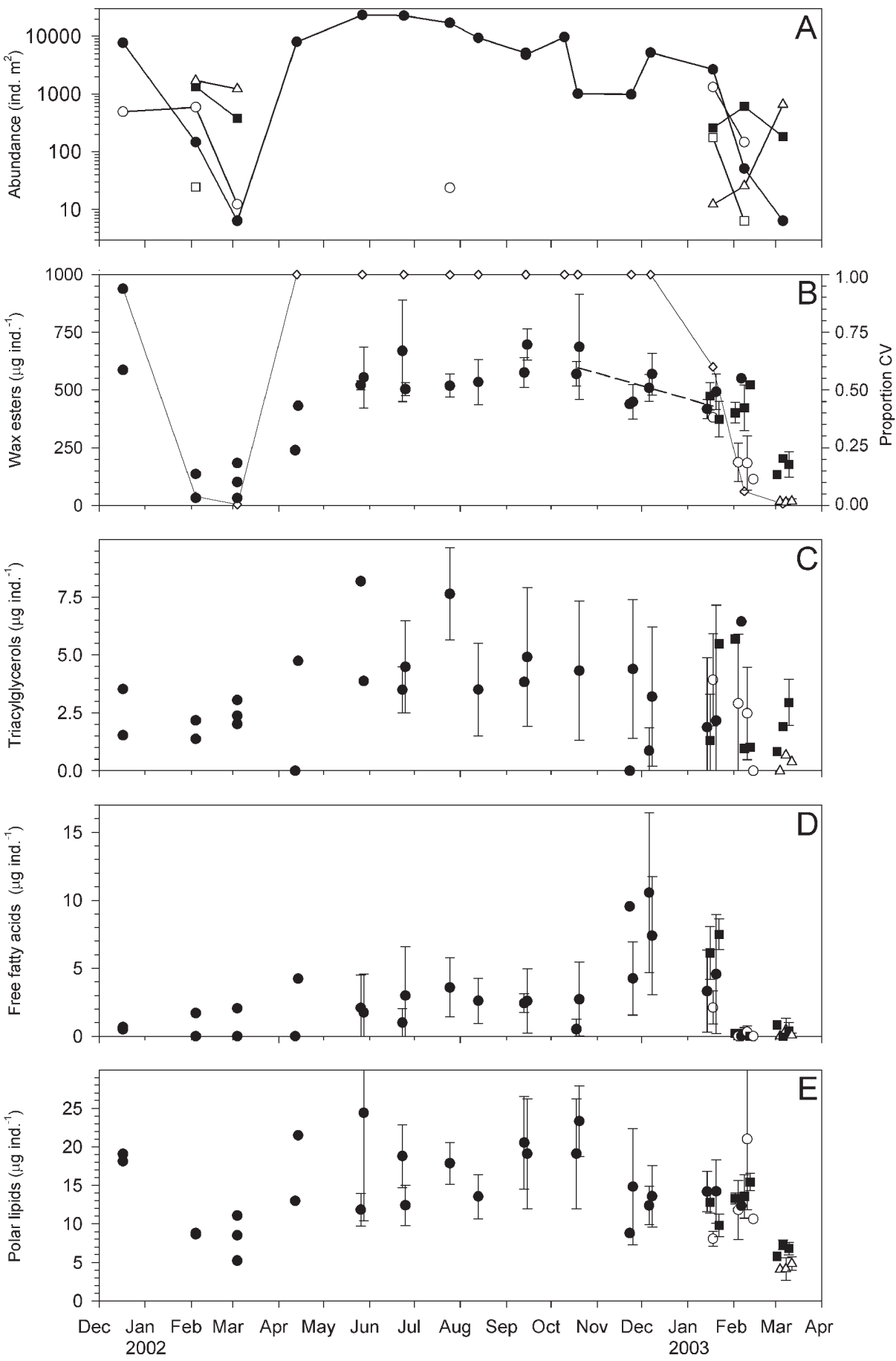

Fig. 2. Neocalanus plumchrus. Seasonal changes in stage and lipid composition of copepods in Strait of Georgia $\left(49^{\circ} 15^{\prime} \mathrm{N}, 123^{\circ} 44.9^{\prime} \mathrm{W}\right)$, December 2001 to March 2003. (A) Abundance of Stage V copepodids and adults, summed over all depths sampled. (B) Right axis $(\diamond)$ shows proportion of CVs; see Fig. 3 for proportions of all adult stages). (B) to (E) Average lipid composition for wax esters, triacylglycerols, free fatty acids and polar lipids respectively (mean \pm SD for replicate samples from each depth stratum). $(\bullet)=C V_{i}(O)=$ males; $(\square)=$ immature females; $(\mathbf{\square})=$ gravid females; $(\Delta)=$ spent females. Overlapping of symbols/SD ranges has been reduced by offsetting symbols slightly from actual sampling dates for lipid data (however, A is a true representation of sampling dates) 

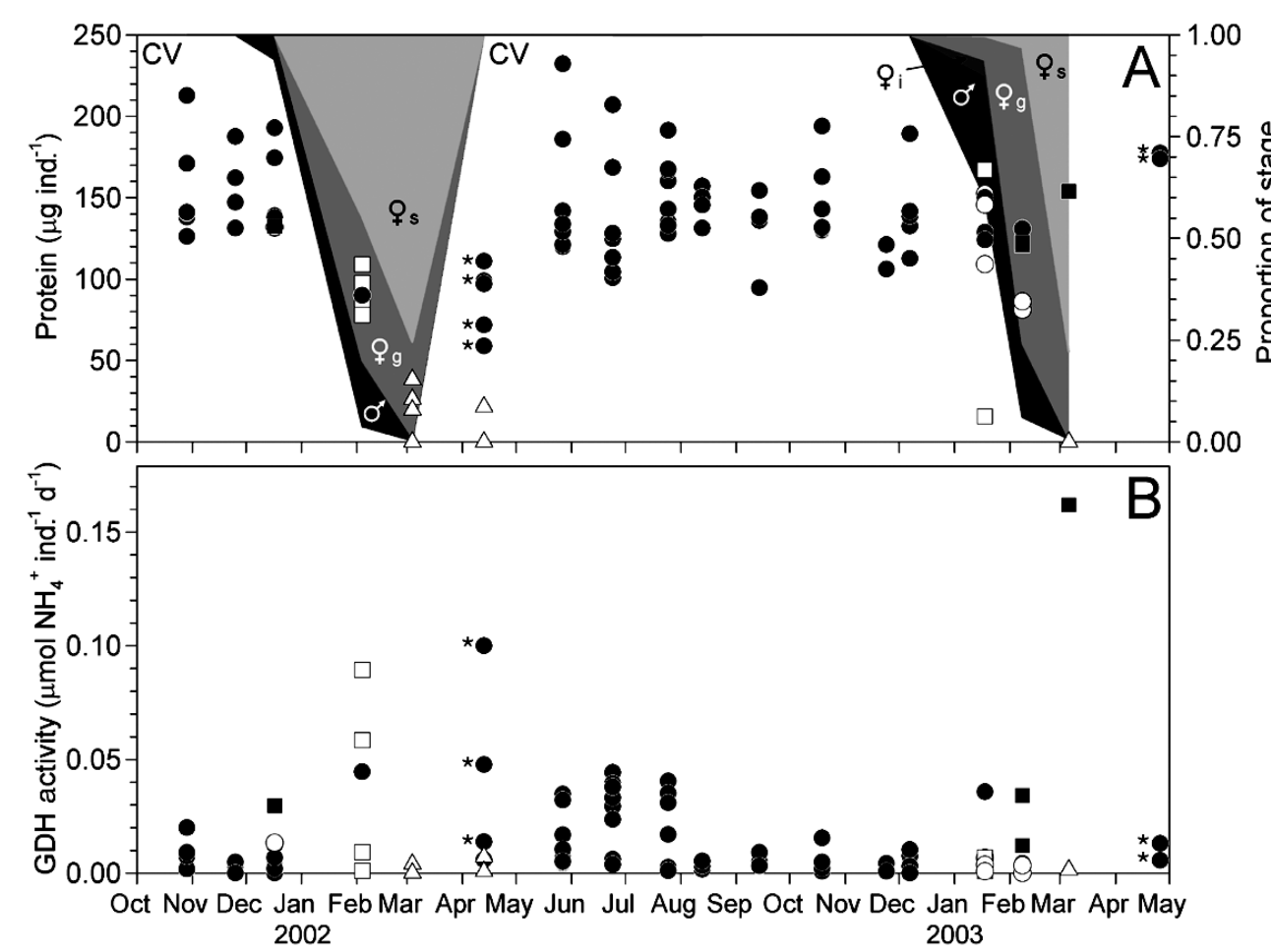

Fig. 3. Neocalanus plumchrus. Seasonal variation in protein contents and GDH activity in copepods from Strait of Georgia, October 2001 to May 2003. (A) Protein content; shaded areas and right axis indicate relative proportions of stage/reproductive state from all counts summed by depth: $q_{1}:$ immature females; og $_{9}$ : gravid females; os $_{\mathrm{s}}$ spent females; see 'Results'). (B) GDH activity; (•) = CV, $(\mathrm{O})=$ males, $(\mathbf{\square})=$ gravid females, $(\Delta)=$ spent females, and $(\square)=$ mixed adults (not sorted by stage). Asterisks denote samples from surface stratum ( 0 to $100 \mathrm{~m}$ )

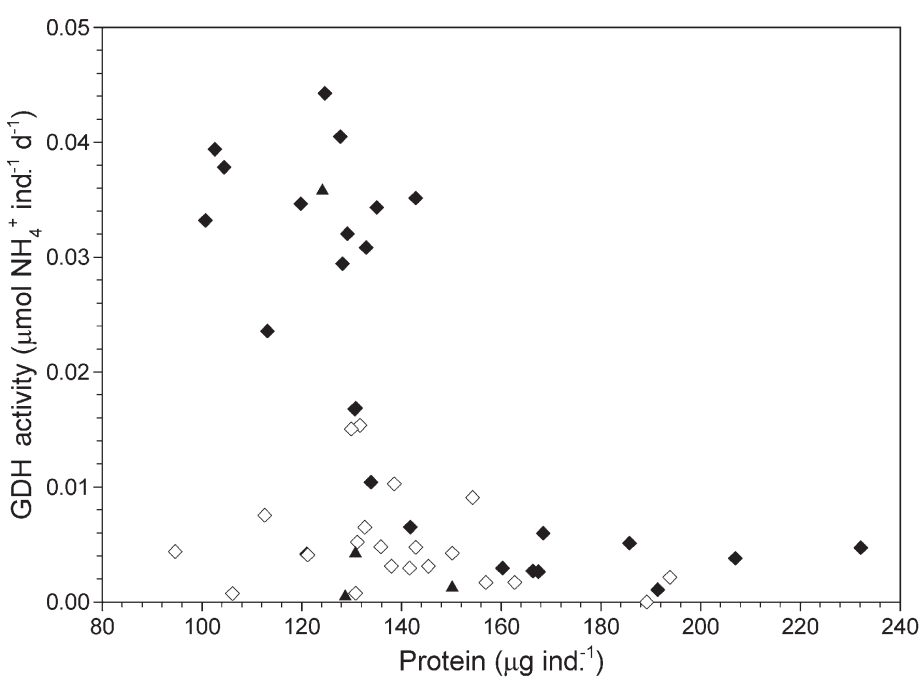

Fig. 4. Neocalanus plumchrus. Relationship between protein content and GDH activity for overwintering CV copepodids from Strait of Georgia, May 2002 to February 2003. Symbols denote collection time: $(\diamond)=$ May to July, $(\diamond)=$ August to December, $(\boldsymbol{\Delta})=$ January \& February

similar to that observed in Calanus finmarchicus by Hirche (1983). Immediately following capture, most individuals were quiescent, many exhibiting the 'overwintering posture' described by Hirche (1983), with first antennae folded ventrally. They were also positively buoyant, and did not respond to handling. Sev- eral hours ( 3 to 6) later, however, most individuals were actively swimming, and initiated escape responses if handled. Several days to $1 \mathrm{wk}$ post-capture, most individuals were observed to be neutrally buoyant and did not swim (except for occasional hops), but still exhibited escape responses when handled.

Moulting from CV to adult occurred from 1 to 2 mo post-capture (Table 1). Moulting did not occur at all during the first incubation (based on 1 observation at Day 104), and there were still CVs present in the second incubation when this was terminated. Moulting was most prolonged during the third incubation. Otherwise, in those incubations initiated during the latter part of the in situ overwintering period (August to October) adults appeared at about the same time during the course of the incubations (usually after 56 to $58 \mathrm{~d}$ ), and moulting occurred over approximately the same time span (Days 92 to 98). Moulting occurred sooner, and over a shorter time span, in early December, and occurred very quickly in January.

There was very little consistent change in TAG, FFA and PL during the course of the incubations. This was probably a result of lower overall sample sizes (a consequence of dividing the small number of individuals in each jar into stage and developmental categories), and the very small amounts of those lipid classes present in a given individual. We will therefore confine our analysis of lipids from the incubations to measurements of WE which, as the predominant lipid class ( $60 \%$ of dry weight), is most quantitative. Measure- 
Table 1. Neocalanus plumbrus. Results of incubation experiments. First column: incubation no., starting date (d/mo/yr), and type of analysis; 3rd, 4th, 5th columns: last day that CVs were present in an incubation, incubation day when adults were first observed, and incubation day when only adults were observed respectively. Regression parameters are for linear model of WE use (WE $=\alpha+\beta t$, where $t=$ time in days) for CV only, see also Fig. 5 ; lines were fit to non-averaged data; WE used by CV $=$ amount of WE consumed during time CV were present (assuming linear decrease, i.e. $\alpha-[\alpha-\beta$ (days CV present)]); proportion WE used $=$ proportion used over same period (i.e. $1-[\alpha-\beta$ (days CV present) $/ \alpha]) ; n=$ number of observations

\begin{tabular}{|c|c|c|c|c|c|c|c|c|c|c|c|}
\hline & $\begin{array}{c}\text { cubation, } \\
\text { analysis }\end{array}$ & $\begin{array}{c}\text { CV last } \\
\text { present } \\
\text { (Day) }\end{array}$ & $\begin{array}{c}\text { Adults first } \\
\text { observed } \\
\text { (Day) }\end{array}$ & $\begin{array}{l}\text { Only } \\
\text { adults } \\
\text { (Day) }\end{array}$ & $\begin{array}{c}\alpha: \\
\text { WE at } t=0 \\
\left(\mu \mathrm{g} \text { ind }^{-1}\right)\end{array}$ & $\begin{array}{c}\beta: \\
\text { WE used } \\
\left(\mu g \text { ind } .^{-1} \mathrm{~d}^{-1}\right)\end{array}$ & $\mathrm{n}$ & $\mathrm{r}^{2}$ & $\mathrm{p}_{\text {ANOVA }}$ & $\begin{array}{c}\text { WE used } \\
\text { by CV } \\
(\mu g)\end{array}$ & $\begin{array}{c}\text { Proportion } \\
\text { WE used }\end{array}$ \\
\hline \multirow{3}{*}{1} & $25 / 06 / 2002$ & & & & & & & & & & \\
\hline & Lipid & 104 & - & - & 641 & 2.72 & 42 & 0.36 & $<0.0001$ & 283 & 0.44 \\
\hline & Enzyme & 104 & - & - & & & & & & & \\
\hline \multirow{3}{*}{2} & 25/07/2002 & & & & & & & & & & \\
\hline & Lipid & 109 & 73 & - & 638 & 3.56 & 38 & 0.51 & $<0.0001$ & 388 & 0.61 \\
\hline & Enzyme & 109 & 109 & - & & & & & & & \\
\hline \multirow{3}{*}{3} & 13/08/2002 & & & & & & & & & & \\
\hline & Lipid & 104 & 56 & 113 & 545 & 3.43 & 33 & 0.40 & $<0.0001$ & 357 & 0.65 \\
\hline & Enzyme & 104 & 84 & 113 & & & & & & & \\
\hline \multirow[t]{3}{*}{4} & 28/08/2002 & & & & & & & & & & \\
\hline & Lipid & 89 & 56 & 98 & 580 & 2.46 & 35 & 0.48 & $<0.0001$ & 219 & 0.38 \\
\hline & Enzyme & 89 & 56 & 106 & & & & & & & \\
\hline \multirow[t]{3}{*}{5} & 14/09/2002 & & & & & & & & & & \\
\hline & Lipid & 97 & 58 & 97 & 584 & 3.37 & 41 & 0.44 & $<0.0001$ & 327 & 0.56 \\
\hline & Enzyme & 97 & 58 & 112 & & & & & & & \\
\hline \multirow[t]{3}{*}{6} & 01/10/2002 & & & & & & & & & & \\
\hline & Lipid & 90 & 55 & 97 & 634 & 3.28 & 27 & 0.40 & 0.0005 & 295 & 0.47 \\
\hline & Enzyme & 77 & 55 & 91 & & & & & & & \\
\hline \multirow[t]{3}{*}{7} & 20/10/2002 & & & & & & & & & & \\
\hline & Lipid & 78 & 56 & 92 & 643 & 4.12 & 35 & 0.38 & 0.0001 & 321 & 0.50 \\
\hline & Enzyme & 78 & 43 & 92 & & & & & & & \\
\hline \multirow[t]{3}{*}{8} & 07/12/2002 & & & & & & & & & & \\
\hline & Lipid & 44 & 28 & 51 & 939 & 7.78 & 29 & 0.34 & 0.0042 & 342 & 0.36 \\
\hline & Enzyme & 37 & 28 & 44 & & & & & & & \\
\hline \multirow{3}{*}{9} & 18/01/2003 & & & & & & & & & & \\
\hline & Lipid & 9 & 23 & 23 & - & - & - & - & - & & - \\
\hline & Enzyme & 9 & 23 & 23 & & & & & & & \\
\hline
\end{tabular}

ments of WE in the CVs are also the most robust, because they were the only stage present early on in the incubations, and thus provided good replication (usually 5 replicates of 4 individuals).

The higher-frequency measurements of WE content at the beginning of the incubations indicate that there was some variability among incubation jars. Appreciable declines in WE content in CVs were apparent after 2 to 4 wk (Fig. 5). WE contents declined more quickly in the incubations than in the field samples (between 2.7 and $7.8 \mu \mathrm{g}$ ind..$^{-1} \mathrm{~d}^{-1}$ ), and a larger total amount was used (219 to $388 \mu \mathrm{g}$ ind. ${ }^{-1}$, i.e. between 36 and $65 \%$ of initial WE content; Table 1). Fitting an exponential decline gave similar results to the linear model in terms of goodness of fit, but tended to underestimate lipid losses, and the latter part of the incubations (i.e. the residuals had a non-zero slope), which is consistent with the fixed cost of maturation suggested by RayRassat et al. (2002).

Protein content generally declined during the course of the incubations, with the greatest declines after moulting to adulthood had occurred (Fig. 6). GDH activity loosely tracked protein content but did not always decline in synchrony (Incubations 5 and 6, notably). GDH activity was not correlated with protein content $(r=-0.06, p=0.61)$. Since it was necessary to pool all individuals from a single incubation jar, the observed protein and enzyme activities are aggregates of all the developmental stages in a jar when that particular incubation was terminated. The exact stage composition of the 'cohorts' varied amongst incubations, making it difficult to infer the extent to which each stage contributed to the observed value. 


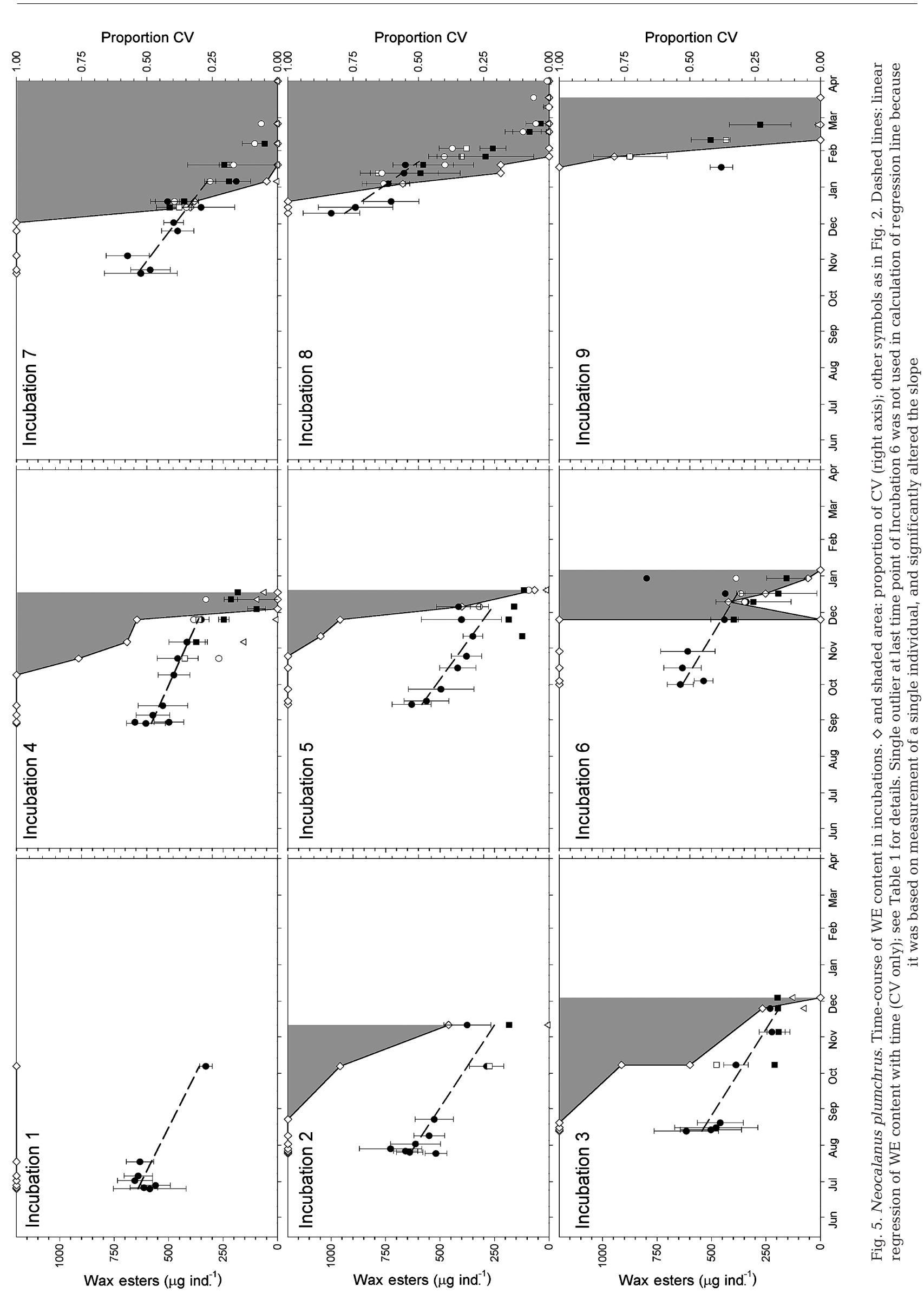




\section{DISCUSSION}

\section{Lipid composition}

Overwintering calanoid copepods are usually characterised by low metabolic rates over much of the overwintering period. However, our observations are consistent with an increase in metabolic activity well in advance of spawning, assuming that the decline began in October. In Balsfjorden, northern Norway, biochemical constituents have been observed to decline in Calanus finmarchicus in advance of the appearance of adults (Tande 1982, Hopkins et al. 1984). Maturation of gonads in phenotypic males and females occurs at the same time (Tande \& Hopkins 1981). A similar pattern in lipid content has also been observed in C. finmarchicus in the English Channel (Gatten et al. 1979).

Work with Neocalanus tonsus in the Subantarctic Pacific and with $N$. plumchrus from the same station sampled in our study has suggested that metabolic reserves are not usually mobilised until very near the time of moulting to adulthood (Ohman et al. 1989, Evanson et al. 2000). The results presented here tell a different story - lipid reserves were mobilised and considerable proportions ( $28 \%$ of WE) of those lipids were used well in advance of actual moulting. The increase in FFA prior to moulting is consistent with lipid catabolism; for instance wax esters must be hydrolysed into their component fatty acid and alcohol prior to being catabolised (Gurr \& Harwood 1991). These differences may stem from the

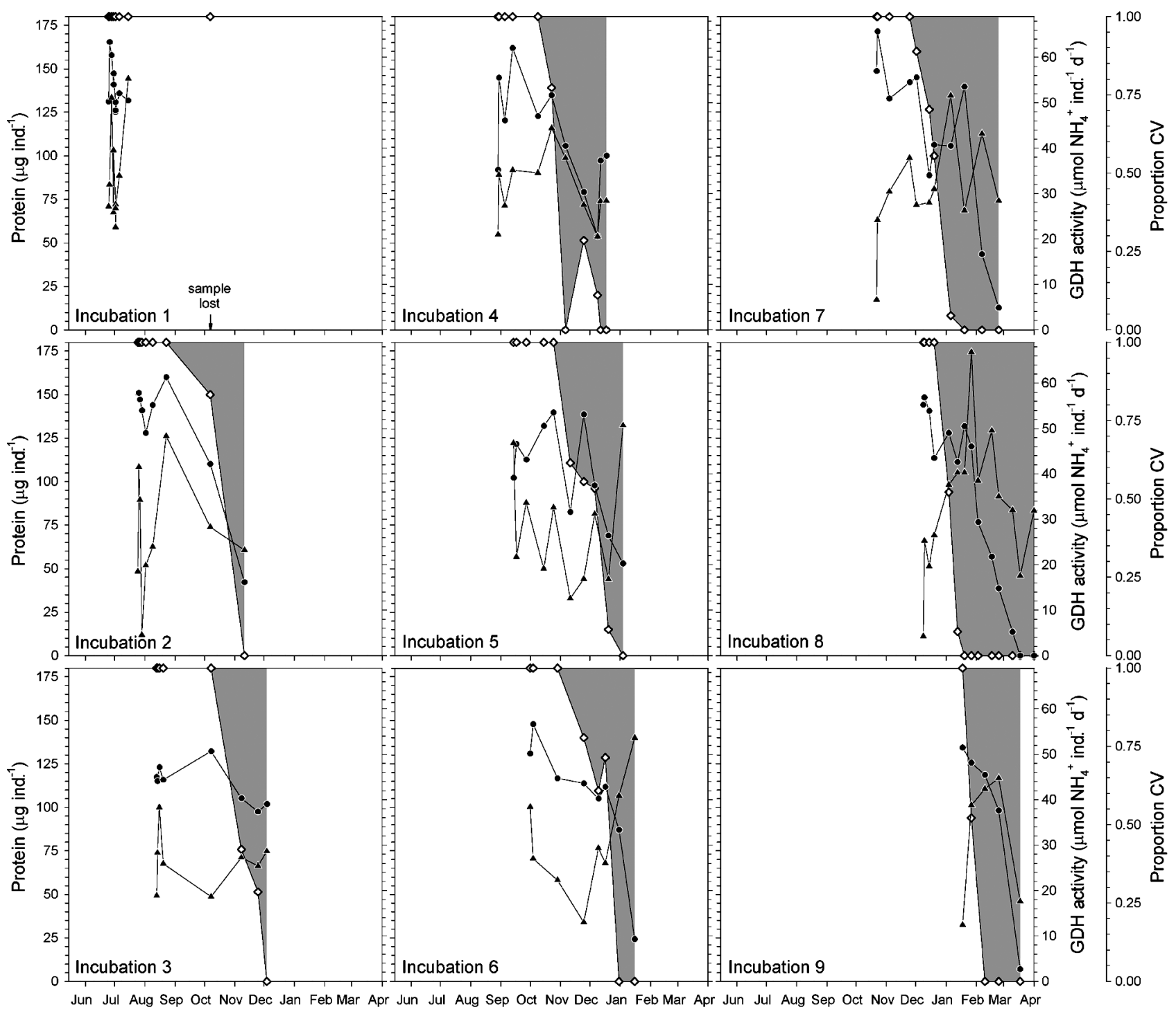

Fig 6. Neocalanus plumchrus. Time course of stage composition, protein content and GDH activity in incubation experiments. $(\diamond$, shaded area $)=$ proportion of $\mathrm{CV}_{i}(\bullet)=$ protein content, $(\mathbf{\Delta})=\mathrm{GDH}$ activity 
fact that the former study (Ohman et al. 1989) had a wider temporal resolution (1 to 2 mo between samples), and the gravimetric measurements of total lipid used in the latter study (Evanson et al. 2000) are sensitive to inclusion of non-lipid materials (Ohman 1997).

In a demographic modelling study, Hind et al. (1999) suggested that normal development processes, operating at reduced, temperature-controlled rates could explain observed patterns in emergence for Calanus finmarchicus in the open North Atlantic. Our results (and those of Tande 1982 and Gatten et al. 1979) suggest that metabolic rates are quite low during much of the overwintering period (May to October, in this study), but do increase in advance of moulting. In many areas of the open ocean, there is no seasonal signal in temperature at depth. For instance, in Balsfjorden, deep-water renewal does not occur until April (and temperature and salinity are invariant prior to then), while moulting to adulthood begins in late January (Eilertsen et al. 1981, Tande 1982). Likewise, during the present study, there was only a small increase $\left(0.5^{\circ} \mathrm{C}\right)$ in temperature at depth (Fig. 1) during the overwintering phase. These results highlight that changes in physiology may be more than environmentally mediated-models based purely on environmental signals are probably oversimplifications, since it is clear that there are physiological (and perhaps behavioural) changes during an organism's life history.

The rate of WE use by CVs from the in situ population was the lowest observed, and the total amount of WE used was also smaller (approximately $28 \%$ as opposed to as much as $64 \%$ in the incubations). There is some circulation at depth in the Strait of Georgia (LeBlond et al. 1991), and so it is possible that we sampled different groups of individuals at different times (i.e. individuals with different nutritional histories from different parts of the Strait). The considerable variability in lipid contents may thus have masked changes in situ. A more accurate indication of lipid use during the termination of overwintering might be expected from the incubation experiments. Each incubation represents an 'artificial cohort', and therefore ought to contain individuals with relatively similar nutritional histories. The incubations therefore represent a somewhat artificial time series of changes in physiology during the termination of the dormant state that interacts with the state of the individuals when they were captured. The higher rates of WE use (and higher overall amount of WE used) in the incubations may therefore be more representative of actual rates of WE use. However, these elevated rates may also have been caused by the less than natural conditions in the incubations (discussed further below).

Very low levels of TAG were observed in both the in situ time series and the incubations, and TAG made up only a very small proportion of the total lipids. TAG is generally considered a 'metabolically active' lipid, and appears to be derived primarily from feeding on phytoplankton (Håkanson 1984). Given that TAG concentrations were very low, and displayed very little seasonality (beyond a decrease in adults), it would appear that synthesis of TAG from WE does not occur during development in Neocalanus plumchrus. The decline in TAG observed prior to spawning in $N$. tonsus by Ohman et al. (1989; although the temporal resolution is suboptimal, see above) is also consistent with this observation. There is very little evidence for transformation of WE to TAG in calanoid copepods. In short-term laboratory incubations, starved Calanus pacificus used all TAG within $\sim 3 \mathrm{~d}$ (Håkanson 1984). Miller et al. (1998) found elevated levels of TAG in C. finmarchicus from the Gulf of Maine in February and March, but the depths from which they were collected and whether or not they were feeding was not reported (and feeding has been observed during winter months in that location: Durbin et al. 1997). Jónasdóttir (1999) observed a small increase in TAG content in deep (>400 m) C. finmarchicus in the Faroe-Shetland Channel between January and February. However, there is no guarantee that the individuals they sampled were from the same population, with the same nutritional history (there is a large amount of transport in that area: Backhaus et al. 1994), and the average values given are statistically indistinguishable (mean \pm SD of $3.3 \pm 3.5$ and $5.4 \pm 2.2 \mu \mathrm{g} \mathrm{TAG} \mathrm{ind} .^{-1}$ with $\mathrm{n}=9$ and $\mathrm{n}=4$ gives mean and $95 \%$ confidence intervals of $3.3 \pm 2.3$ and $5.4 \pm 2.2$ for January and February respectively; Jónasdóttir 1999, her Fig. 4). The low, fairly constant TAG levels observed here may therefore reflect TAG bound up in structural or functional components of the copepods, as suggested by Miller et al. (1998).

The polar lipids include phospholipids (structural components of membranes), glycolipids (functional components of membranes such as receptors), pigments, and non-lipid residues (Parrish 1987). In zooplankton, polar lipids appear to be primarily phospholipids (Parrish 1998), with smaller amounts of glycolipids and pigments (Parrish et al. 2000). The production of gonads would, of course, require phospholipids for the construction of membranes, and given that Neocalanus plumchrus does not eat during gonadogenesis, any phospholipids used would need to come from internal reserves. The drop in polar lipid content observed in females (Fig. 2E) would then have been caused in part by losses due to spawning (Ohman et al. 1989 found that $66 \%$ of $N$. tonsus egg lipids were phospholipids).

\section{Protein contents}

Since the period when young stages of Neocalanus plumchrus are present in surface waters is very brief 
(Fulton 1973), and the sampling frequency of the field population was approximately monthly, active CVs were observed in surface waters only once per year. In April 2002, surface-dwelling CVs had comparatively low protein and high GDH activity, while CVs in April 2003 had higher protein content and low GDH activity. This suggests that the individuals sampled in 2002 were actively growing and catabolising ingested protein, while in 2003 they had essentially finished structural growth and were pre-dormant.

Protein contents did not change appreciably during the overwintering period in the Strait of Georgia Neocalanus plumchrus population. Curiously, during the earliest part of the overwintering period, GDH activities were highest in measurement groups that contained the lowest amount of protein, but activity was almost universally low towards the end of the overwintering period (Fig. 3B). Since GDH 'activity' is really a measurement of the amount of enzyme, it is possible that the high 'activities' observed early in overwintering are actually an indication of a supply of GDH left over from growth while near the surface during the spring. However, this is inconsistent with the low GDH activities observed in surface-dwelling CVs in April 2003. Also curious is the high protein content observed in some measurement groups early (but not later) on in the overwintering period. This may have resulted from protein catabolism (inconsistent with the low GDH activities observed), or simply from sampling different subpopulations with different nutritional histories.

Other studies have observed low ammonium excretion rates in overwintering calanoids, suggesting that little protein metabolism occurs (Conover \& Corner 1968). Cowen (1982) observed extremely low excretion rates in overwintering Neocalanus plumchrus CVs from Saanich Inlet, that were almost an order of magnitude lower than those of Conover \& Corner (1968). The results presented here are consistent with a decline in protein metabolism during overwintering. However, there is still considerable variability (presumably driven by variability in the physiological states of individuals: Båmstedt 1988): the high GDH activity early on in the overwintering period suggests a considerable lag for changes in physiology. A similar lag has also been observed in traditional measurements of electron transport system (ETS) activity using the Owens \& King method (Mayzaud 1986).

It has been proposed that copepods use protein as a metabolic substrate during overwintering in order to preserve lipid stores for reproduction (Kirkesæter 1977, Jónasdóttir 1999, Schnack-Schiel 2001). It has also been suggested that protein may be used to fuel egg release in Neocalanus plumchrus (Evanson et al. 2000). The onset of moulting by the Strait of Georgia N. plumchrus population was not accompanied by a large drop in protein content (unlike that observed in WE). A decline in pro- tein content was observed in males and spent females (and the 'mixed' samples from 2002 indicate a decline also); this is to be expected with the onset of mating (in males) or spawning. Considerable protein may be lost during spawning in females (e.g. Guisande \& Harris 1995 cite a value of 57 to $59 \%$ protein for the eggs of Calanus helgolandicus). GDH activity was higher in gravid females, indicating the possibility of an increase in protein metabolism related to egg production.

Measurements of protein from the incubations did not show a consistent decline in the early part of the incubations (i.e. when only CV were present). Protein contents did decrease after moulting had begun, but GDH activity did not change in concert with protein content, as might be expected if active protein catabolism were occurring. Pooling all individuals from an incubation for a single measurement certainly obscures stage-specific patterns: different stages (i.e. developing CVs, males, and immature, gravid and spent females) probably use their protein contents in different ways. For instance, females must use some of their protein reserves for the production of eggs, while males may invest far less protein in the construction of their much smaller gonads. Stage-specific measurements will be required to clear up this uncertainty.

\section{Termination of dormancy}

There is considerable plasticity in the dormancy behaviour of overwintering calanoid copepods. Although overwintering dormancy is usually characterised by low physical and physiological activity (see Hirche 1996), the dormant state is interrupted if the copepods are disturbed. In this study, copepods that were initially quiescent when captured did not return to the dormant state. Rather, they appeared to switch towards development of gonads (as evidenced by a decrease in lipid), and moulting to adulthood. There was, however, a lag of several weeks before moulting occurred, and moulting tended to occur more quickly in individuals collected closer to the 'natural' moulting period of individuals in situ (Fig. 5, Table 1).

The CVs in at least the first 6 incubations (prior to November) were in a dormant state when collected, assuming that one accepts that the lack of significant lipid or protein use in the in situ population indicates low metabolic activity. In those incubations, moulting was less likely to occur (i.e. CVs were present longer) and adults took longer to appear (never appearing in the first incubation, although the temporal resolution was poor). In the latter 4 incubations (collected when lipid contents were already declining in situ) there was a progression towards earlier, and more synchronised, moulting (Figs. $5 \& 6$, Table 1). This is consistent with 
observations by Fulton (1973), who observed that Neocalanus plumchrus collected in September had not moulted and still contained significant lipid in December. Such a change in behaviour in the absence of any external environmental cues suggests that $N$. plumchrus possesses an endogenous clock that modulates physiology over fairly long-time scales, but that development becomes imperative once it has been switched on. Similarly, Conover (1965) found that when kept in the laboratory without any environmental stimuli $\mathrm{Ca}$ lanus hyperboreus moulted sychronously with in situ populations almost $1 \mathrm{yr}$ after collection.

During 'classical' diapause (sensu Danks 1987), dormancy is maintained until some stimulus is received that prompts the organism to terminate dormancy. The suggestion of an endogenous rhythm is consistent with a physiologically controlled diapause state, and endogenous rhythms have been identified in other invertebrates during diapause (Blake 1959, Olive \& Garwood 1983, reviewed in insects by Hodek 2002). Results from the incubations suggest that, during the process of being collected, the copepods receive enough stimulation to prompt them to terminate dormancy and continue their development. Although we made every effort to capture them as gently as possible, a certain amount of disturbance (and a short-term increase in light and temperature) was unavoidable. We cannot conclude from our data which stimulus (or combination of stimuli) it is that prompts dormancy termination in Neocalanus plumchrus.

Why, then, do Neocalanus plumchrus exhibit a highly synchronised life history but do not exhibit dormancy in laboratory incubations? Although the dormant state appears to be fragile, it does not appear to terminate spontaneously in the in situ population. Results of the incubations suggest that the copepods do have some knowledge of the time of year, and delay moulting earlier on. An obvious cue that was missing from the incubations is pressure. If N. plumchrus has a preferred pressure that is used to maintain position in the water column, but is unable to achieve that depth, this may trigger a 'decision' to break overwintering and continue development. Calanus finmarchicus has been observed to change its behaviour in response to small changes in pressure such as are experienced during diel migration (Rice 1962), and a mechanism for baroreception has recently been observed in a decapod crustacean (Fraser et al. 2001). The pressure physiology of copepods is essentially unknown, and merits further study.

It is perhaps not surprising that dormancy in Neocalanus plumchrus appears to be a rather fragile state. The conditions experienced by overwintering zooplankton are considerably more dynamic than those experienced by terrestrial insects, upon which most diapause research has been conducted. Overwintering copepods must maintain their vertical position in the water column, where they are presumably displaced by tidal and residual currents. The Strait of Georgia is a large estuarine system, and deep-water renewal occurs regularly in late summer, when gravity-flows over the sill to the south end of the Strait inject warm, salty water to depth (LeBlond et al. 1991; present Fig. 1). Deep water renewal events may therefore result in vertical displacements of overwintering $N$. plumchrus, and will alter in situ sea water density, which can affect the buoyancy properties of the copepods (Campbell \& Dower 2003). A 'hardwired' dormancy state would be disadvantageous in such an environment, and it seems more probably that the overwintering copepods fine-tune their position occasionally, and then return to dormancy once they experience the proper conditions. Some degree of activity during the dormant state is not contrary to a true diapause state, for instance activity has been noted in several insect species during diapause (Hodek 2002). In an environment as dynamic as the marine pelagial, some activity is perhaps to be expected.

Copepods are significant grazers of oceanic primary production (e.g. Calbet 2001), and serve as prey to higher trophic levels (e.g. Cushing 1975); a thorough knowledge of the factors mediating their life history is of value. The use of field studies to elucidate physiological mechanisms clearly has drawbacks - sampling at a high enough frequency is difficult and expensive, and there is no guarantee that the same population will be present (thus increasing the apparent variance). Similarly, simulation of overwintering conditions in vitro presents considerable challenges, although they are not insurmountable (e.g. see Torres et al. 1982). Development of techniques that allow the stimulation and maintenance of copepod dormancy in the laboratory will be required in order to properly describe physiological changes during their life history.

Acknowledgements. We thank the 6 anonymous reviewers for their comments on earlier versions of the manuscript; the officers and crew of CCGS 'Vector', CCGS 'Neocaligus' and RV 'John Strickland'; and David Jones, Hugh Maclean and the numerous graduate and undergraduate volunteers for their technical and field assistance. This work was supported by a University of Victoria Graduate Fellowship to R.W.C. and a Natural Sciences and Engineering Research Council of Canada Discovery grant to J.F.D.

\section{LITERATURE CITED}

Ackman, RG, McLeod, CA, Banerjee, AK (1990) An overview of analyses by chromarod-Iatroscan TLC-FID. J Planar Chromatogr 3:450:462

Backhaus JO, Harms IH, Krause M, Heath MR (1994) An hypothesis concerning the space-time succession of 
Calanus finmarchicus in the northern North Sea. ICES J Mar Sci 51:169-180

Båmstedt U (1988) Ecological significance of individual variability in copepod bioenergetics. Hydrobiologia 167/168: $43-59$

Berges JA, Roff JC, Ballantyne JS (1993) Enzymatic indices of respiration and ammonia excretion: relationships to body size and food levels. J Plankton Res 15:239-254

Bidigare RR, King FD (1981) The measurement of glutamate dehydrogenase activity in Praunus flexuosus and its role in the regulation of ammonium excretion. Comp Biochem Physiol B 70:409-413

Bidigare RR, King FD, Biggs DC (1982) Glutamate dehydrogenase $(\mathrm{GDH})$ and respiratory electron-transport-system (ETS) activities in Gulf of Mexico zooplankton. J Plankton Res 4:895-911

Blake GM (1959) Control of diapause by an 'internal clock' in Anthrenus verbasci (L.) (Col, Dermestidae). Nature 183: $126-127$

Calbet A (2001) Mesozooplankton grazing effect on primary production: a global comparative analysis in marine ecosystems. Limnol Oceanogr 46:1824-1830

Campbell RW, Dower JF (2003) Role of lipids in the maintenance of neutral buoyancy by zooplankton. Mar Ecol Prog Ser 263:93-99

Carlisle DB, Pitman WJ (1961) Diapause, neurosecretion and hormones in copepoda. Nature 190:827-828

Comita GW, Marshall SM, Orr AP (1966) On the biology of Calanus finmarchicus. XIII. Seasonal change in weight, calorific value and organic matter. J Mar Biol Assoc UK 46: $1-17$

Conover RJ (1965) Notes on the molting cycle, development of sexual characteristics and sex ratio in Calanus hyperboreus. Crustaceana 8:308-320

Conover RJ (1988) Comparative life histories in the genera Calanus and Neocalanus in high latitudes of the northern hemisphere. Hydrobiologia 167/168:127-142

Conover RJ, Corner EDS (1968) Respiration and nitrogen excretion by some marine zooplankton in relation to their life cycles. J Mar Biol Assoc UK 48:49-75

Corner EDS, Cowey CB (1968) Biochemical studies on the production of marine zooplankton. Biol Rev 43:393-426

Cowen MB (1982) Overwintering strategies of the calanoid copepod Calanus plumchrus in a periodically anoxic British Columbia fjord. MSc thesis, Naval Postgraduate School, Monterey

Cushing DH (1975) Marine ecology and fisheries. Cambridge University Press, Cambridge

Dahms H (1995) Dormancy in the Copepoda-an overview. Hydrobiologia 306:199-211

Danks HV (1987) Insect dormancy: an ecological perspective. Monogr Ser Can Wildl Serv 1:1-439

Durbin EG, Runge JA, Campbell RG, Garrahan PR, Casas MC, Plourde S (1997) Late fall-early winter recruitment of Calanus finmarchicus on Georges Bank. Mar Ecol Prog Ser 151:103-114

Eilertsen HC, Falk-Petersen S, Hopkins CCE, Tande K (1981) Ecological investigations on the plankton community of Balsfjorden, northern Norway: program for the project, study area, topography, and physical environment. Sarsia 66:25-34

Evanson M, Bornhold EA, Goldblatt RH, Harrison PJ, Lewis AG (2000) Temporal variation in body composition and lipid storage of the overwintering, subarctic copepod Neocalanus plumchrus in the Strait of Georgia, British Columbia (Canada). Mar Ecol Prog Ser 192:239-247

Folch J, Lees M, Sloan Stanley GH (1957) A simple method for the isolation and purification of total lipids from animal tissues. J Biol Chem 226:497-509

Fraser PJ, Macdonald AG, Cruickshank SF, Schraner MP (2001) Integration of hydrostatic pressure information by identified interneurones in the crab Carcinus maenas (L.); long-term recordings. J Navig Fluv Marit 54:71-79

Fulton J (1973) Some aspects of the life history of Calanus plumchrus in the Strait of Georgia. J Fish Res Board Can 30:811-815

Gatten RR, Corner EDS, Kilvington CC, Sargent JR (1979) A seasonal survey of the lipids in Calanus helgolandicus Claus from the English Channel. In: Naylor E, Hartnoll RG (eds) Cyclic phenomena in marine plants and animals: Proc 13th Eur Mar Biol Symp, Isle of Man, 27 September4 October 1978. Pergamon Press, New York, p 275-284

Gatten RR, Sargent JR, Forsberg TEV, O'Hara SCM, Corner EDS (1980) On he nutrition and metabolism of zooplankton: XIV. Utilisation of lipid by Calanus helgolandicus during maturation and reproduction. J Mar Biol Assoc UK 60:391-399

Grigg H, Bardwell SJ (1982) Seasonal observations on moulting and maturation in stage $\mathrm{V}$ copepodites of Calanus finmarchicus from the Firth of Clyde. J Mar Biol Assoc UK 62:315-327

Guisande C, Harris R (1995) Effect of total organic content of eggs on hatching success and naupliar survival in the copepod Calanus helgolandicus. Limnol Oceanogr 40: $476-482$

Gurr MI, Harwood JL (1991) Lipid biochemistry, 4th edn. Chapman \& Hall, London

Håkanson JL (1984) The long and short term feeding condition in field-caught Calanus pacificus, as determined from the lipid content. Limnol Oceanogr 29:794-804

Hernández-León S, Torres S (1997) The relationship between ammonia excretion and GDH activity in marine zooplankton. J Plankton Res 19:587-601

Hind A, Gurney WSC, Heath M, Bryant AD (2000) Overwintering strategies in Calanus finmarchicus. Mar Ecol Prog Ser 193:95-107

Hirche HJ (1983) Overwintering of Calanus finmarchicus and Calanus helgolandicus. Mar Ecol Prog Ser 11:281-290

Hirche HJ (1989) Spatial distribution of digestive enzyme activities of Calanus finmarchicus and C. hyperboreus in Fram Strait/Greenland Sea. J Plankton Res 11:431-443

Hirche HJ (1996) Diapause in the marine copepod, Calanus finmarchicus - a review. Ophelia 44:129-143

Hodek I (2002) Controversial aspects of diapause development. Eur J Entomol 99:163-173

Hopkins CCE, Tande KS, Gronvik S, Sargent JR (1984) Ecological investigations of the zooplankton community of Balsfjorden, northern Norway: an analysis of growth and overwintering tactics in relation to niche and environment in Metridia longa (Lubbock), Calanus finmarchicus (Gunnerus), Thysanoessa inermis (Krøyer) and T. raschi (M. Sars). J Exp Mar Biol Ecol 82:77-99

Ikeda T, Torres JJ, Hernández-León S, Geiger SP (2000) Metabolism. In: Harris RP, Wiebe PH, Lenz J, Skjoldal HR, Huntley M (eds) ICES zooplankton methodology manual. Academic Press, London, p 455-532

Johnson CL (2003) Ecdysteroids in the oceanic copepod Calanus pacificus: variation during molt cycle and change associated with diapause. Mar Ecol Prog Ser 257: 159-165

Jónasdóttir SH (1999) Lipid content of Calanus finmarchicus during overwintering in the Faroe-Shetland Channel. Fish Oceanogr 8(Suppl 1):61-72

Kehoe JJ (2003) Total marine lipid profiling by short column 
gas chromatography. MSc thesis, Memorial University of Newfoundland, St. John's

Kirkesæter P (1977) Biomasseundersøkelse av Calanus finmarchicus i Korsfjorden 1974-1975, belyst ved kalorimetri og biokjemiske analyser. Hovedfagsoppgav, Universitete Bergen, Norway (cited after Hirche 1996)

Koroleff F (1983) Determination of ammonia. In: Grasshoff K, Ehrhardt M, Kremling K (eds) Methods of seawater analysis, 2nd edn. Verlag Chemie, Weinheim, p 150-157

Kosobokova KN (1990) Age-related and seasonal changes in the biochemical makeup of the copepod Calanus glacialis as related to the characteristics of its life cycle in the White Sea. Oceanology 30:103-108

LeBlond PH, Ma H, Doherty F, Pond S (1991) Deep and intermediate water replacement in the Strait of Georgia. Atmos-Ocean 29:288-312

Mackas DL, Tsuda A (1999) Mesozooplankton in the eastern and western subarctic Pacific: community structure, seasonal life histories, and interannual variability. Prog Oceanogr 43:335-363

Marshall SM, Orr AP (1958) On the biology of Calanus finmarchicus X: seasonal changes in oxygen consumption. J Mar Biol Assoc UK 37:459-472

Mayzaud P (1986) Enzymatic measurements of metabolic processes concerned with respiration and ammonia excretion. In: Corner EDS, O'Hara SCM (eds) The biological chemistry of marine copepods. Clarendon Press, Oxford, p 226-259

Miller CB, Frost BW, Batchelder HP, Clemons MJ, Conway RE (1984) Life histories of large, grazing copepods in a subarctic ocean gyre: Neocalanus plumchrus, Neocalanus cristatus, and Eucalanus bungii in the northeast Pacific. Prog Oceanogr 13:201-243

Miller CB, Grigg H (1991) An experimental study of the resting phase in Calanus finmarchicus. Bull Plankton Soc Jpn Spec Vol:479-493

Miller CB, Cowles TJ, Wiebe PH, Copley NJ, Grigg H (1991) Phenology in Calanus finmarchicus; hypotheses about control mechanisms. Mar Ecol Prog Ser 72:79-91

Miller CB, Morgan CA, Prahl FG, Sparrow MA (1998) Storage lipids of the copepod Calanus finmarchicus from Georges Bank and the Gulf of Maine. Limnol Oceanogr 43:488-497

Motoda S (1959) Devices of simple plankton apparatus. Mem Fac Fish Hokkaido Univ 7:73-94

Ohman MD (1988) Sources of variability in measurements of copepod lipids and gut fluorescence in the California Current coastal zone. Mar Ecol Prog Ser 42:143-153

Ohman MD (1997) On the determination of zooplankton lipid content and the occurrence of gelatinous copepods. J Plankton Res 19:1235-1250

Ohman MD, Bradford JM, Jillett JB (1989) Seasonal growth and lipid storage of the circumglobal, subantarctic copepod, Neocalanus tonsus (Brady). Deep-Sea Res 36:1309-1326 Olive PJW, Garwood PR (1983) The importance of long term

Editorial responsibility: Thomas Kiørboe (Contributing Editor), Charlottenlund, Denmark endogenous rhythms in the maintenance of reproductive cycles of marine invertebrates: a reappraisal. Int $\mathrm{J}$ Invertebr Reprod 6:339-347

Owens TG, King FD (1975) The measurement of respiratory electron-transport-system activity in marine zooplankton. Mar Biol 30:27-36

Parrish CC (1987) Separation of aquatic lipid classes by chromarod thin-layer chromatography with measurement by Iatroscan flame ionisation detection. Can J Fish Aquat Sci 44:722-731

Parrish CC (1998) Lipid biogeochemistry of plankton, settling matter and sediments in Trinity Bay, Newfoundland. I. Lipid classes. Org Geochem 29:1531-1545

Parrish CC, Ackman RG (1985) Calibration of the Iatroscanchromarod system for marine lipid classes. Lipids 20: 521-530

Parrish CC, Abrajano TA, Budge SM, Helleur RJ, Hudson ED, Pulchan K, Ramos C (2000) Lipid and phenolic biomarkers in marine ecosystems: analysis and applications. In: Wangersky P (ed) The handbook of environmental chemistry, Vol 5, Part D. Springer-Verlag, Berlin, p 193-223

Rey-Rassat C, Irigoien X, Harris R, Carlotti F (2002) Energetic cost of gonad development in Calanus finmarchicus and C. helgolandicus. Mar Ecol Prog Ser 238:301-306

Read H (1985) Improved sample application methods for the Iatroscan. Lipids 20:510-515

Rice AL (1962) Responses of Calanus finmarchicus (Gunnerus) to changes in hydrostatic pressure. Nature 194: 1189-1190

Runge JA (1987) Measurement of egg production rate of Calanus finmarchicus from preserved samples. Can J Fish Aquat Sci 44:2009-2012

Schnack-Schiel SB (2001) Aspects of the study of the life cycles of Antarctic copepods. Hydrobiologia 453/454:9-24

Smith PK, Krohn RI, Harmanson GT, Mallia AK and 6 others (1985) Measurement of protein using bicinchoninic acid. Anal Biochem 150:76-85

Tande KS (1982) Ecological investigations on the zooplankton community of Balsfjorden, northern Norway: generation cycles, and variations in body weight and body content of carbon and nitrogen related to overwintering and reproduction in the copepod Calanus finmarchicus (Gunnerus). J Exp Mar Biol Ecol 62:129-142

Tande KS, Hopkins CCE (1981) Ecological investigations of the zooplankton community of Balsfjorden, northern Norway: the genital system in Calanus finmarchicus and the role of gonad development in overwintering strategy. Mar Biol 63:159-164

Tauber MJ, Tauber CA, Masaki S (1986) Seasonal adaptations of insects. Oxford University Press, New York

Torres JJ, Childress JJ, Quetin LB (1982) A pressure vessel for the simultaneous determination of oxygen consumption and swimming speed in zooplankton. Deep-Sea Res 29: 631-639

Submitted: September 26, 2003; Accepted: June 2, 2004

Proofs received from author(s): September 20, 2004 